\title{
ACCESS TO ENTREPRENEURSHIP, CAPITAL AND MARKETING WITH BANK SAMPAH (WASTE BANKS) PROGRAM
}

\author{
Dian Primanita Oktasari \\ Faculty of Economics and Business, Mercu Buana University \\ dprimanita88@gmail.com
}

\begin{abstract}
Waste Banks is an alternative waste management in Indonesia. Waste Bank at RPTRA Maneuver is one of the Waste Banks that has been established in Kecamatan Kembangan. Qualitative research is used to see the effectiveness of waste management in the RPTRA Maneuver from the perspective of the aspect of waste management. There are still many obstacles experienced by the community to be able to process waste into selling or worthy materials. During this time, community participation has been good enough, but not optimal. This is because knowledge and understanding are not evenly distributed. Operational engineering aspects have been running effectively but place constraints are the main problem.
\end{abstract}

Keywords: Waste banks, waste, entrepreneurship education, and entrepreneur

\section{INTRODUCTION}

Jakarta is threatened to be overwhelmed by garbage. The amount of waste produced by Jakarta residents reaches 7,000 tons per day. If the matter is not handled seriously, the capital city of Jakarta can be a waste emergency status. West Jakarta, as one of the regions with high density and quite large area is West Jakarta, contributes to the problem in DKI Jakarta. Based on data from DKI Sanitation Department, over the past year, the volume of waste transported from West Jakarta to Bantar Gebang dump reached 44,249.17 tons.

Nevertheless, the problem of garbage in the capital city must be resolved from many aspects; starting from the addition of the fleet, transporting the garbage, and also the participation of the community in managing the waste so that the problem is not only burdened to the DKI Sanitation Department. West Jakarta region has 215 fleet units for transporting the waste. However, it is not enough to overcome the problem in the capital city. Therefore, an active role of the community is needed in managing the waste. For this reason, it is hoped that the community can continue to develop waste banks, reduce, reuse, and recycle (3R), composting and others in their respective regions. Currently, there are 459 active waste banks in West Jakarta area.

\section{LITERATURE REVIEW}

\section{Definition of Waste Banks}

The role of Waste Bank is important in accordance with the issuance of Government Regulation No. 81 in 2012 concerning Household Waste Management that requires producers to carry out 3R activities by producing products that use an easy-to-decomposed packaging. Statistics on the development of Waste Bank construction at Kembangan Sub-district in 2017 are 64 units in which 52 units are active Waste Banks and 12 units are in pending status.

\section{Definition of Management}

Terry (2010) defined management as a process or framework that involves the guidance of a group of people to achieve the goals. Follet (1997) said that management is an art. Therefore, every task can be done using the concepts of planning, organizing, implementing and controlling in order to achieve the company goals by using their respective styles and methods. 


\section{Waste Management}

According to Azwar (1990: 53), waste is something that cannot be used and must be discarded. Therefore, waste must be managed as well as possible to prevent negative impacts. Kodoatie (2003) explained garbage as solid or semi-solid waste, which is a by-product of urban activities or the life cycle of humans, animals and plants. In environmental health science, garbage (refuse) is actually a part of objects or things to be obsolete, disliked or must be discarded for the sake of life sustainability. SK SNI $\mathrm{T}-13-1990 \mathrm{~F}$ also stated that garbage is solid waste consisting of organic and inorganic substances.

\section{METHOD}

In dealing with problems that occur in partner community as described, the Community Partnership Program offered some approach methods to assist in resolving the existing problems by conducting training and counselling methods to produce some economic valued products.

During the implementation of this Partnership Program, the community will be given some trainings and mentoring activities:

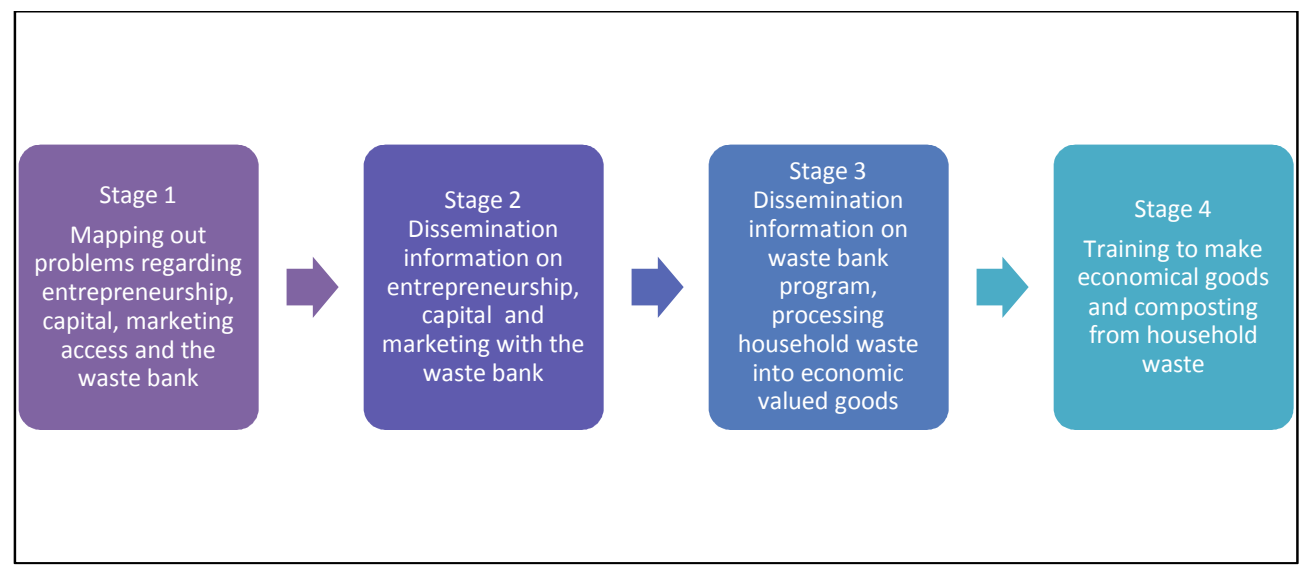

Figure 1. Stages of Training Activities

Skill trainings to sort waste which include:

a. Sorting out organic waste

This training is to develop the ability to sort organic waste for composting,

b. Sorting out inorganic waste

This training is to develop the ability to sort inorganic waste in the form of plastic that can be recycled to make handicrafts. Plastic bottles or paralon pipes can be used as planting containers for hydroponic plants.

\section{Waste processing training} goods.

This training is aimed to provide skills in the process of recycling waste into economic valued

\section{Motivational and entrepreneurial managerial skill trainings}

It is aimed to motivate the participants for entrepreneurship and the ability to manage business, which include: a) Motivational training, b) Creating business plans, d) Operations and production management, e) Marketing management, and f) Basic financial management and accounting.

\section{Mentoring for trainees}

It is aimed to give some insights and how to apply managerial skills. 


\section{RESULTS AND DISCUSSION}

West Jakarta covered an estimated area of $124.44 \mathrm{Km}$ consisting 8 districts; 56 administrative villages; 580 community groups; and 6,409 neighborhood groups. With an estimated population of $2,278,825$ people, the volume of waste produced is approximately 1500 tons / day as shown in Table 1.2 and Figure 1.2

Table 1. Waste Volume Data in 2016

\begin{tabular}{||c||l||c||c||c|}
\hline \hline No & \multicolumn{1}{|c|}{ Districts } & $\begin{array}{c}\text { Production } \\
\text { per day m3 }\end{array}$ & $\begin{array}{c}\text { Served } \\
\text { per day }\end{array}$ & $\begin{array}{c}\text { Not } \\
\text { transported } \\
\text { per day }\end{array}$ \\
\hline \hline 1 & Kembangan & 621 & 612 & 10 \\
\hline 2 & Kebon Jeruk & 867 & 853 & 15 \\
\hline 3 & Palmerah & 722 & 718 & 4 \\
\hline 4 & Grogol Petamburan & 1046 & 1035 & 11 \\
\hline 5 & Tambora & 1241 & 1253 & 8 \\
\hline 6 & Taman Sari & 858 & 853 & 6 \\
\hline 7 & Cengkareng & 1086 & 1067 & 19 \\
\hline 8 & Kalideres & 756 & 741 & 16 \\
\hline
\end{tabular}

The demographic data of administrative villages at Kembangan district in 2016 is as follows

\begin{tabular}{|c|c|c|c|c|c|c|c|}
\hline \multirow[b]{2}{*}{ No } & \multirow{2}{*}{$\begin{array}{l}\text { Kelurahan } \\
\text { Sub district }\end{array}$} & \multirow{2}{*}{$\begin{array}{l}\text { Luas } \\
\text { Wilayah } \\
\text { Total } \\
\text { Area } \\
\left(\mathrm{Km}^{2}\right)\end{array}$} & \multicolumn{4}{|c|}{$\begin{array}{c}\text { Jumlah } \\
\text { Total } \\
\end{array}$} & \multirow{2}{*}{$\begin{array}{c}\text { Kepadatan } \\
\text { Pendudulk } \\
\text { (jiwa/ } / \mathrm{Km}^{2} \text { ) } \\
\text { Population } \\
\text { Density } \\
\text { (People/K } \\
\mathrm{m}^{2} \text { ) }\end{array}$} \\
\hline & & & RT & RW & $\begin{array}{c}\text { KK } \\
\text { Fomilly } \\
\text { Head }\end{array}$ & $\begin{array}{l}\text { Penduduk } \\
\text { Population }\end{array}$ & \\
\hline (1) & (2 & (3) & (4) & (5) & (6) & (7) & (8) \\
\hline 1 & Joglo & 4.85 & 115 & 9 & 13875 & 44448 & 9164 \\
\hline 2 & Srengseng & 4.91 & 98 & 12 & 15593 & 49025 & 998 \\
\hline 3 & $\begin{array}{l}\text { Meruya } \\
\text { Selatan }\end{array}$ & 2.80 & 84 & 11 & 10882 & 34361 & 1227 \\
\hline 4 & Meruya Utara & 4.33 & 126 & 11 & 15748 & 47451 & 1095 \\
\hline 5 & $\begin{array}{l}\text { Kembangan } \\
\text { Selatan }\end{array}$ & 3.61 & 77 & 9 & 9390 & 29227 & 809 \\
\hline 6 & $\begin{array}{l}\text { Kembangan } \\
\text { Utara }\end{array}$ & 3.64 & 118 & 11 & 19247 & 59830 & 1643 \\
\hline & Jumlah & 24.14 & 618 & 63 & 84.73! & 264342 & 10950 \\
\hline
\end{tabular}

Sumber/Source : Suku Dinas Kependudukan dan Pencatatan Sipil Kota Jakarta Barat

Figure 2. Demographic data at Kembangan District in 2016

However, the problem of garbage in the capital city must be resolved from many aspects; starting from the addition of the fleet, transporting the garbage, and also the participation of the community in managing the waste so that the problem is not only burdened to the DKI Sanitation Department. Today, West Jakarta region has 215 fleet units for transporting of waste. However, it is not enough to overcome the problem in the capital city. Therefore, an active role of the community is needed in managing the waste. For this reason, it is hoped that the community can continue to develop waste banks, reduce, reuse, and recycle (3R), composting and others in their respective regions. Currently, there are 459 active waste banks in West Jakarta area as shown in Table 1.3. 
Table 2. Number of Waste Bank at West Jakarta Municipality in 2017

\begin{tabular}{|c|l|c|c|c|}
\hline \multirow{2}{*}{ No } & \multirow{2}{*}{ District } & Total & \multicolumn{2}{|c|}{ Status } \\
\cline { 3 - 5 } & & Waste Bank & Active & Pending \\
\hline 1 & Kembangan & 64 & 52 & 12 \\
\hline 2 & Kebon Jeruk & 48 & 48 & 0 \\
\hline 3 & Cengkareng & 49 & 49 & 0 \\
\hline 4 & Grogol & 56 & 53 & 3 \\
\hline 5 & Kalideres & 70 & 69 & 1 \\
\hline 6 & Palmerah & 60 & 60 & 0 \\
\hline 7 & Tambora & 78 & 78 & 0 \\
\hline 8 & Taman Sari & 60 & 50 & 10 \\
\hline & Jumlah & 485 & 459 & 26 \\
\cline { 2 - 5 }
\end{tabular}

Based on the data above, it can be concluded that social mapping must increase the number and function of waste bank to reduce its volume in the landfill, also to create new entrepreneurs by utilizing recycled inorganic waste.

\section{CONCLUSION}

Overall, the socialization participants were mostly housewives living in the child-friendly integrated public space of Manuver environment at Unilever Housing. The atmosphere during socialization was quite lively as the participants were curious about how to manage waste and to utilize them into economic valued goods. The participants said that this program is interesting because they can learn new things; get new insights about how to recycle plastic waste and composting.

As from the initial questionnaire given to 30 people, 20 people still did not understand how to sort, process and utilize plastic waste into economic valued goods, the waste bank facility was not maximized yet and there were no trained personnel for the waste bank. As from the final questionnaire given to 30 people, 29 people have understood how to sort, process and utilize plastic waste into economic valued goods. Waste bank facility can be optimized by forming waste bank personnel. Moreover, this activity can be served as a means of communication, friendship and dissemination of information from Mercu Buana University to the society, as well as social responsibility of the institution.

\section{Recommendation}

It is recommended to make routine scheduling and mentoring activities in running the program or activity.

\section{Acknowledgment}

Gratitude and honor to the editors who have reviewed the ICCD 2018 paper Mercu Buana University Jakarta,Dr. Inge Hutagalung, M.Si., Head of Community Service at Mercu Buana University, Dudi Permana Ph.D., Head of Management Undergraduate Program, Soelton Ibrahim S.Psi., MM. CHRMP, Secretary of Management Undergraduate Program, Ryani Dhyan Parashakt, SE, MM. Secretary of Management Undergraduate Program 


\section{REFERENCES}

Azwar, Azrul. (1990). Pengantar Ilmu Lingkungan. Jakarta: Mutiara Sumber Widya.

BPS Kota Adm Jakarta Barat. (2018). Data Volume Sampah 2016

(http://data.jakarta.go.id/dataset/data-volume-sampah, diakses tanggal 29 Juli 2018).

BPS Kota Adm Jakarta Barat. (2017). Kecamatan Kembangan Dalam Angka 2017. (https://jakbarkota.bps.go.id/publication/download, diakses tanggal 29 Juli 2018).

Follet, Mary Parker. (1997) Defenition of Management http://www.blog.re.or.id/defenisimanajemen.htm (diakses tanggal 25 Februari 2017).

Soegoto, E. S. (2014). Entrepreneurship Menjadi Pebisnis Ulung Edisi Revisi. Elex Media Komputindo.

Kodoatie, R. J. (2003). Manajemen dan Rekayasa Infrastruktur. Pustaka Pelajar.

Profil Bank Sampah Indonesia, (2013), Kementrian Lingkungan Hidup.

SK SNI S-04-1993-03 tentang Spesifikasi Timbulan Sampah untuk Kota Besar dan Kota Sedang.

Suku Dinas Lingkungan Hidup Kota Administrasi Jakarta Barat. (2018). Data Bank Sampah Kota Administrasi Jakarta Barat. (http://data.jakarta.go.id/dataset/data-bank-sampah, diakses tanggal 29 Juli 2018).

Suku Dinas Lingkungan Hidup Kota Administrasi Jakarta Barat. (2018). Data Bank Sampah Kota Administrasi Jakarta Barat. (http://data.jakarta.go.id/dataset/data-bank-sampah, diakses tanggal 29 Juli 2018).

Terry, G. R., \& Rue, L. W. (2010). Dasar-Dasar Manajemen, Cetakan Ke-Sebelas Jakarta: PT. Bumi Aksara. 